medRxiv preprint doi: https://doi.org/10.1101/2021.06.03.21258279; this version posted October 11,2021 . The copyright holder for this preprint (which was not certified by peer review) is the author/funder, who has granted medRxiv a license to display the preprint in It is made available under a CC-BY-ND 4.0 International license .

Impact of Angelman syndrome on parental productivity

\title{
Estimating the impact of Angelman syndrome on parental productivity in Australia using productivity-adjusted life years
}

Authors: Sally L Hartmanis ${ }^{1}$, Emma K Baker ${ }^{2,3,4}$, David E Godler ${ }^{2,3}$, Danny Liew ${ }^{1}$

${ }^{1}$ School of Public Health and Preventive Medicine, Monash University, 553 St Kilda Road, Melbourne, Victoria 3004, Australia

${ }^{2}$ Diagnosis and Development, Murdoch Children's Research Institute, Royal Children's

Hospital, 50 Flemington Road, Parkville, Victoria 3052, Australia

${ }^{3}$ Faculty of Medicine, Dentistry and Health Sciences, Department of Paediatrics, University of Melbourne, Parkville, Victoria 3010, Australia

${ }^{4}$ School of Psychology and Public Health, La Trobe University, Plenty Road and Kingsbury

Drive, Bundoora, Victoria 3086, Australia

\section{Corresponding author}

Sally L Hartmanis

School of Public Health and Preventive Medicine

Monash University

553 St Kilda Road, Melbourne

Victoria 3004 Australia

sally.hartmanis@angelmansyndrome.org 
medRxiv preprint doi: https://doi.org/10.1101/2021.06.03.21258279; this version posted October 11, 2021. The copyright holder for this preprint (which was not certified by peer review) is the author/funder, who has granted medRxiv a license to display the preprint in It is made available under a CC-BY-ND 4.0 International license

\begin{abstract}
Angelman syndrome (AS) is a severe neurodevelopmental condition associated with a significant socioeconomic impact. This is the first study to estimate the impact of AS on parental productivity in Australia using cost-of-illness modelling with simulated follow-up over a 10-year period using 2019 as the baseline year. Key data were obtained from a prospective cohort of AS families, peer-reviewed literature, and publicly-available sources. The base-case productivity burden borne by the estimated 330 living parents of the 428 prevalent-persons with AS totalled AUD $\$ 1.25$ million, corresponding to a loss of $38.42 \%$ of PALYs per-parent. This shows that caring for a child with AS has a significant impact on the productivity of affected parents, with a large associated impact on the broader Australian economy.
\end{abstract}

Keywords: Angelman syndrome, Intellectual disability, Parents, Productivity burden, Costof-illness, Economic impact 
medRxiv preprint doi: https://doi.org/10.1101/2021.06.03.21258279; this version posted October 11, 2021. The copyright holder for this preprint (which was not certified by peer review) is the author/funder, who has granted medRxiv a license to display the preprint in It is made available under a CC-BY-ND 4.0 International license .

\section{Introduction}

Angelman syndrome (AS) is a rare genetic neurodevelopmental condition characterised by global developmental delay, including severe to profound intellectual disability, absent speech, motor function impairment, and significant behavioural challenges such as insomnia, hyperactivity, excessive smiling and laughing, obsession with water, and repetitive and aggressive behaviours (Khan et al., 2019b, 2019a; Wheeler et al., 2017). Persons with AS also often experience multiple comorbidities, including epilepsy, cerebral palsy, scoliosis, and blindness and other visual impairments (Jørgensen et al., 2019; Wheeler et al., 2017). In addition, persons with AS have been demonstrated to exhibit symptoms associated with autism spectrum disorder (Baker et al., 2018). As such, persons with AS require lifelong care and support (Khan et al., 2019a).

Estimates of AS prevalence vary greatly from 1 in 10,000 to 1 in 86,250 (Jørgensen et al., 2019; Petersen et al., 1995). Furthermore, many of the studies claiming to report a population prevalence have determined the prevalence of AS within a small sample of persons with intellectual disability, followed by extrapolation to the total population (Wheeler et al., 2017). The epidemiological characteristics of AS do not appear to differ by race (Luk \& Lo, 2016). This large degree of variability may be attributed to a number of factors, including the absence of a newborn screening program for AS to allow for estimates on cohorts of unbiased ascertainment, overlapping phenotypic characteristics with other syndromes, issues pertaining to the accuracy of diagnostic methods, the lack of genetic confirmation for approximately $10 \%$ of cases, the establishment of a global registry only in 2016, and historically low levels of awareness among clinicians (Õiglane-Shlik et al., 2006; Thomson et al., 2006; Tones et al., 2018; Wheeler et al., 2017). The latter is driven by a number of factors, including that AS was only first described in 1965, the major genetic mechanism was not recognised until the 1980s, and consensus regarding the clinical 
medRxiv preprint doi: https://doi.org/10.1101/2021.06.03.21258279; this version posted October 11,2021 . The copyright holder for this preprint (which was not certified by peer review) is the author/funder, who has granted medRxiv a license to display the preprint in It is made available under a CC-BY-ND 4.0 International license .

Impact of Angelman syndrome on parental productivity

diagnostic criteria was only achieved in 1995 (Buntinx et al., 1995; Thomson et al., 2006;

Wheeler et al., 2017). Many of these factors mean that children with AS, and their families, are often subject to a 'lengthy diagnostic odyssey' with most only receiving a diagnosis between the ages of one and five years (Wheeler et al., 2017). Arguments for more systematic diagnostic efforts for AS have been made elsewhere (Baker et al., 2021).

AS results in a significant socioeconomic impact, both on the healthcare system and affected families (Wheeler et al., 2017). Persons with AS require a high-level of specialist medical care within both an outpatient and inpatient setting, with the most frequent causes of hospitalisation comprising care for oral-dental issues, seizures, orthopaedic problems, and acute respiratory disorders (Domínguez-Berjón et al., 2018; Khan et al., 2019b). This is most pronounced among young children with AS, who tend to require a greater number of surgeries and hospitalisations, and who need to spend more time in hospital once admitted (Khan et al., 2019b). Furthermore, the care required by persons with AS when undergoing routine health-related procedures often involves a significantly greater use of resources due to the need for additional interventions (Thomson et al., 2006). These can include, for example, a general anaesthetic when visiting the dentist for a routine teeth cleaning service (Thomson et al., 2006). In addition, persons with AS often require many pharmaceuticals either for directly treating the symptoms of their condition or one of the recognised comorbidities of AS, with almost $80 \%$ of children aged six years requiring at least one medication (despite the fact that there is no specific therapeutic treatment for AS) (Jørgensen et al., 2019; Khan et al., 2019b, 2019a; Wheeler et al., 2017). Furthermore, the parents of persons with AS are at significant risk of stress and other mental health problems. This risk is greater than that experienced by the parents of persons with autism, Cornelia de Lange syndrome and Cri du Chat syndrome (Griffith et al., 2011). This impact is particularly notable for mothers of children with AS (Griffith et al., 2011; van den Borne et al., 1999; Wulffaert et al., 2010). 
medRxiv preprint doi: https://doi.org/10.1101/2021.06.03.21258279; this version posted October 11, 2021. The copyright holder for this preprint (which was not certified by peer review) is the author/funder, who has granted medRxiv a license to display the preprint in It is made available under a CC-BY-ND 4.0 International license.

Impact of Angelman syndrome on parental productivity

Despite the above considerations, there remains limited evidence regarding the productivity impact borne by the parents of persons with AS, with very little published data regarding the adverse effects on parents' employment and productivity (Grieco et al., 2019; Khan et al., 2019b; Thomson et al., 2017; Wheeler et al., 2017; Willgoss et al., 2020). This impact can be quantified using productivity-adjusted life years (PALYs), which is a measure of the productivity burden imposed by a given condition (Ademi et al., 2021). PALYs are useful for estimating and communicating productivity impacts because they can be compared across conditions and populations to inform policy and funding decisions (Ademi et al., 2021). PALYs are a function of the life years lived by a given population and their corresponding productivity index. The productivity index ranges from zero (completely unproductive) to one (completely productive) and is a measure of workforce participation, time off work (absenteeism), and reduced productive output while at work (presenteeism) (Ademi et al., 2021; Giovannetti et al., 2009). Each of these components are known to impact the parents of persons with AS (Grieco et al., 2019; Khan et al., 2019b; Thomson et al., 2017; Wheeler et al., 2017; Willgoss et al., 2020).

This study aimed to estimate, for the first time, the total productivity lost by the parents of persons with AS over a 10-year period in Australia and the corresponding cost to society. It was hypothesised that caring for a person with AS has a significant impact on the productivity of affected parents, with a large associated impact on the broader Australian economy.

\section{Methods}

The study was approved by the Royal Children's Hospital Human Research Ethics Committee (reference number 33066) and the Monash University Human Research Ethics Committee (reference number 2021-25930-55113). All parents/caregivers provided written 
medRxiv preprint doi: https://doi.org/10.1101/2021.06.03.21258279; this version posted October 11, 2021. The copyright holder for this preprint (which was not certified by peer review) is the author/funder, who has granted medRxiv a license to display the preprint in It is made available under a CC-BY-ND 4.0 International license.

Impact of Angelman syndrome on parental productivity

informed consent and participants who were deemed cognitively able also provided written informed consent.

\section{Modelling approach}

The productivity burden borne by the parents of persons with AS in Australia was estimated using cost-of-illness modelling with simulated follow-up, facilitated by a Markov chain of life tables, over a 10-year period with 2019 as the baseline year. This involved estimating the prevalence of persons with AS and their parents, the PALYs lost by parents, and the associated cost to society. The model structure is depicted in Figure S1.

Key data were obtained from a prospective cohort of families of children with AS who participated in a natural history study of chromosome 15 imprinting disorders (Baker et al., 2018, 2021), peer-reviewed literature, and publicly-available data reported by the Australian Bureau of Statistics (ABS). The data analyses and supporting assumptions are discussed in the following sections, with further detail provided in Tables S1-2. Approaches were aligned to the applicable sections of the Consolidated Health Economic Evaluation Reporting Standards (CHEERS) statement for health interventions (Husereau et al., 2013).

\section{Data analysis}

Prevalence of $A S$

The prevalence of AS in Australia was estimated by determining the population prevalence of AS, the age and sex distribution of prevalent AS, and the average life expectancy of persons with AS.

No studies reporting the population prevalence of AS in Australia were identified and variation across the reported estimates in other countries was significant. One study reporting 
medRxiv preprint doi: https://doi.org/10.1101/2021.06.03.21258279; this version posted October 11, 2021. The copyright holder for this preprint (which was not certified by peer review) is the author/funder, who has granted medRxiv a license to display the preprint in It is made available under a CC-BY-ND 4.0 International license.

Impact of Angelman syndrome on parental productivity

the incidence of AS in Australia was identified, with significant variation also observed across the other available estimates (Thomson et al., 2006).

All results were estimated for a lower, base-case, and upper prevalence scenario to account for the underlying uncertainty in the prevalence of AS within Australia. Estimates of AS prevalence were applied to the total number of Australians in 2019 reported by the ABS to derive the total number of prevalent AS cases (National, State and Territory Population, 2020).

The base-case prevalence estimate was obtained from an Australian retrospective record review which identified 26 persons with AS having been born in Western Australia during the 50 years that Disability Services Commission (DSC) records were kept, corresponding to a live birth incidence of 1:40,000 among a birth population of 1.05 million (Thomson et al., 2006). This estimate was selected as the base-case prevalence estimate due to the proximal relationship of incidence and prevalence in rare disease, and the crossover of the Thomson et al (2006) study population (Western Australians) with the target population of this study (Australians). The other available estimates of AS incidence are greater than that reported by Thomson et al (2006), with a retrospective record review in China having identified 55 patients with AS from 1995-2015, corresponding to a birth incidence of 1:22,305 among a live birth population of 1,226,780 (Luk \& Lo, 2016). Similarly, in Denmark, a retrospective registry review identified 51 patients with AS from 1991-2009, corresponding to a birth incidence of 1:24,580 among a birth population of 1,250,000 (Mertz et al., 2013).

The lower prevalence estimate was obtained from a retrospective registry review in Denmark, which identified 80 patients with AS out of the 6.90 million patients in the Danish National Patient Registry (DNPR) from 1994 to 2015, corresponding to a prevalence of 
medRxiv preprint doi: https://doi.org/10.1101/2021.06.03.21258279; this version posted October 11,2021 . The copyright holder for this preprint (which was not certified by peer review) is the author/funder, who has granted medRxiv a license to display the preprint in It is made available under a CC-BY-ND 4.0 International license.

Impact of Angelman syndrome on parental productivity

1:86,250 (0.001\%) (Jørgensen et al., 2019). While, the upper prevalence estimate was obtained from an evaluation of patients referred to a university hospital in Denmark, which identified five patients with AS over five years, corresponding to a prevalence of 1:10,000 $(0.01 \%)$ (Petersen et al., 1995). The other available estimates of AS population prevalence fall within this range, with a prospective focused search in Estonia having identified 6 live individuals with AS from 2000-2004, corresponding to a prevalence of 1:56,112 (ÕiglaneShlik et al., 2006). Similarly, a Saudi Arabian prospective screening study identified 1 child with AS out of 45,682 children screened from 2004-2005, corresponding to a prevalence of 1:50,000 (Al Salloum et al., 2015).

The age and sex distribution of prevalent AS was assumed to follow the same distribution as that of prevalent disability in Australia in 2018 as reported by the ABS (Disability, Ageing and Carers, 2018). This approach assumed that the prevalence of AS within each age group was equally distributed within that age group. The average life expectancy of persons with AS was assumed to be 70 years (Coppus, 2013; Dagli et al., 2011).

\section{Prevalence of the parents of persons with AS}

The prevalence of the parents of persons affected by AS was estimated by determining the average parental age during the year that each child with AS was born. This was estimated by deriving a weighted average of maternal and paternal age, respectively, for the required years using data reported by the ABS (Births, 2019). This approach assumed that the parents of persons with AS had the same average age as all Australians when their child was born. In addition, this approach assumed that each person with AS had one biological mother and one biological father who experienced productivity impacts attributable to AS. 
medRxiv preprint doi: https://doi.org/10.1101/2021.06.03.21258279; this version posted October 11, 2021. The copyright holder for this preprint (which was not certified by peer review) is the author/funder, who has granted medRxiv a license to display the preprint in It is made available under a CC-BY-ND 4.0 International license.

Impact of Angelman syndrome on parental productivity

\section{PALYs lost}

The PALYs lost by this prevalent group of parents were estimated by comparing the PALYs lived by this group, with the PALYs lived by a simulated control group. This simulated control group allowed for the estimation of a counterfactual scenario in which the parents of persons with AS did not have a child with AS and, therefore did not experience any productivity impacts attributable to AS. It was assumed that the mortality rate of persons with AS had a negligible impact on the AS attributable productivity impacts experienced by parents. PALYs accrued beyond the first year of the modelled simulation were discounted at 5.0\% per annum (Larg \& Moss, 2011).

The number of life years lived by the parental and simulated control groups were estimated via the construction of a Markov chain of age and sex specific life tables to simulate the progress of the parental and control groups over a 10-year period, adjusted for background mortality (Deaths, 2019). Each group was followed until a maximum age of 70 years. Separate life tables were constructed for 20 age and sex sub-cohorts, with age stratified into 10 five-year age groups from 20-24 years to 65-69 years. The starting age in each subcohort was the mid-point of that age group. The 20-69 years age range was selected to reflect the ages during which people were commonly engaged in paid employment. It was assumed that there was no mortality attributable to being the parent of a person with AS, meaning life years lived in the parental and simulated control groups were the same. As such, the difference in the PALYs lived by each group was driven by their respective productivity indices.

The productivity index of the parental group was derived by estimating this group's average workforce participation, and the level of absenteeism and presenteeism attributable to having a child with AS. Uncertainty in these inputs was accounted for in sensitivity 
medRxiv preprint doi: https://doi.org/10.1101/2021.06.03.21258279; this version posted October 11,2021 . The copyright holder for this preprint (which was not certified by peer review) is the author/funder, who has granted medRxiv a license to display the preprint in It is made available under a CC-BY-ND 4.0 International license.

analyses in which the estimated parental average workforce participation, and attributable absenteeism and presenteeism were varied by $+/-20 \%$.

The average workforce participation of the parents of persons with AS was estimated using data collected from a prospective cohort of families of children with AS who participated in a natural history study of chromosome 15 imprinting disorders (Baker et al., 2021). A Client Service Receipt Inventory (CSRI) modified to be suitable for AS assessments in Australia and Participant Developmental and Medical Anamnesis (PDMA) questionnaire were distributed to 28 parents of persons with AS (Baker et al., 2021). The parents responded to the questionnaires on behalf of themselves and their spouse/partner. A sub-set of these data were used to derive the average workforce participation of 50 individual parents of persons with AS. As such, it was estimated that average workforce participation was $97.3 \%$ for fathers and $47.4 \%$ for mothers. This approach assumed that the workforce participation reported by this sample size was reflective of the average workforce participation of the parents of persons with AS across all age groups included in the analysis.

No studies estimating absenteeism and presenteeism attributable to being the parent of a person with AS were identified. Therefore these inputs were estimated using the results from a study of the caregiver burden attributable to Dravet syndrome (DS) (Campbell et al., 2018). The overlap in the AS and DS phenotypes has been described elsewhere (Willemsen et al., 2012). Campbell et al (2018) measured caregiver productivity impairment using a subset of the Work Productivity and Activity Impairment (WPAI) questionnaire; a tool which has been validated for eliciting attributable caregiver productivity loss (Ademi et al., 2021; Campbell et al., 2018; Giovannetti et al., 2009). Of parents remaining in the workforce, their mean time missed from work each week ranged from 6.9 to 7.4 hours, while their productive output at work was impacted by 39.1 to $76.9 \%$ (Campbell et al., 2018). The mid-points of each of these ranges ( 7.2 hours and 58.0\%, respectively) were used as inputs in the analysis. 
medRxiv preprint doi: https://doi.org/10.1101/2021.06.03.21258279; this version posted October 11, 2021. The copyright holder for this preprint (which was not certified by peer review) is the author/funder, who has granted medRxiv a license to display the preprint in It is made available under a CC-BY-ND 4.0 International license.

Impact of Angelman syndrome on parental productivity

This approach assumed that the parental absenteeism and presenteeism attributable to DS was a reasonable approximation of the parental absenteeism and presenteeism attributable to AS.

The productivity index of the simulated control group was derived by estimating the average workforce participation of the general population. This was estimated using age and sex specific ABS employment data for 2019 (Characteristics of Employment, 2020). This dataset includes data pertaining to adults with and without children, including children with disabilities. As such, it was assumed that the data approximated the average workforce participation of the control population. Absenteeism and presenteeism were not estimated for the general population because relative absenteeism and presenteeism measures attributable to AS were applied.

\section{Cost to society}

The cost to society resulting from this lost productive output was estimated by multiplying the number of PALYs lost within each age and sex sub-cohort included in the analysis by the average gross domestic product (GDP) per full-time equivalent (FTE) worker specific to that sub-cohort (Ademi et al., 2021; National Income, Expenditure and Product, 2020). GDP per FTE is a function of GDP per hour worked per person adjusted for the proportion of FTEs within each age and sex sub-cohort (Characteristics of Employment, 2020; National Income, Expenditure and Product, 2020). This assumed that the hourly contributions to GDP made by parents who worked were the same as the average for all working Australians.

\section{Results}

Prevalence of persons with AS and their parents

The prevalence of AS in Australia in 2019 was estimated to total 428 (lower: 171, upper: 1,714) persons (Figure 1). The prevalence of the parents of persons affected by AS in 
medRxiv preprint doi: https://doi.org/10.1101/2021.06.03.21258279; this version posted October 11,2021 . The copyright holder for this preprint (which was not certified by peer review) is the author/funder, who has granted medRxiv a license to display the preprint in It is made available under a CC-BY-ND 4.0 International license

Impact of Angelman syndrome on parental productivity

Australia in 2019 between the ages of 20 and 69 years was estimated to total 330 (lower: 132, upper: 1,322) persons (Figure 2).

\section{PALYs lost and cost to society}

The productivity burden borne by the parents of persons with AS in Australia over a 10-year period was estimated to total 183.40 (lower: 73.36, upper: 1,321.58) PALYs (fathers), 311.66 (lower: 124.66, upper: 733.60) PALYs (mothers), and 495.06 (lower: 198.02, upper: 1,246.62) PALYs (total) (Table 1). These values were discounted, as described in the Methods section. This corresponded to a loss of $25.19 \%$ of PALYs (fathers), $53.05 \%$ of PALYs (mothers) and $38.42 \%$ of PALYs (average) per-parent (Table 1). As expected, the proportion of PALYs lost was greatest between the ages of 30 and 54 years (Figure 3).

This productivity impact corresponded to a societal cost of AUD $\$ 19.98$ (lower: $\$ 7.99$, upper: \$79.93) million (fathers), AUD\$25.32 (lower: \$10.13, upper: \$101.27) million (mothers), and AUD\$45.30 (lower: \$18.12, upper: \$118.20) million (total) (Table 1). This equated to a per-parent cost of AUD\$128,252.16 (fathers), AUD\$145,007.16 (mothers), and AUD\$137,105.94 (average) (Table 1). These values were discounted by 5\%.

\section{Sensitivity analyses}

When reviewing the results of the sensitivity analyses across the prevalence scenarios estimated, it is clear that the paternal results are most sensitive to fluctuations in the key parental productivity index inputs (Figure ). This is likely due to the extremely high average paternal workforce participation estimated. In addition, variations in the presenteeism inputs resulted in significant variation in the results. 
medRxiv preprint doi: https://doi.org/10.1101/2021.06.03.21258279; this version posted October 11, 2021. The copyright holder for this preprint (which was not certified by peer review) is the author/funder, who has granted medRxiv a license to display the preprint in It is made available under a CC-BY-ND 4.0 International license.

\section{Discussion}

The present study highlights the significant impact that caring for a child with AS imposes on parents' productivity, and the broader economy. Mothers bear the bulk of this burden, while by contrast, fathers have higher workforce participation than the average population. The latter may be reflective of a productivity impact in reverse, in which fathers are forced or encouraged to remain in fulltime employment at greater levels than they otherwise would have. This is potentially associated with mental health and quality of life impacts not captured in the present study. As expected, the socioeconomic cost of this lost productivity was greatest during parents' prime working years.

The present study fills an important gap in the literature by quantifying and monetising the productivity burden borne by the parents of persons with AS. A number of studies have qualitatively explored this topic (Grieco et al., 2019; Miodrag \& Peters, 2015; Thomson et al., 2017; Wheeler et al., 2017; Willgoss et al., 2020). However, these studies did not quantify or monetise the parental productivity impact of AS, nor did they estimate any potential positive impacts arising from caring for a child with AS. Previous studies have found that the challenging behaviours which characterise AS are associated with increased parental stress which, in turn, is associated with poor parental health. In particular, the sleep issues experienced by persons with AS, such as insomnia; wake time after sleep onset; fragmented sleep; and variability in total sleep time, are a major cause of parental stress and are also linked with higher rates of parental insomnia and daytime drowsiness (Goldman et al., 2012; Grieco et al., 2019; Wheeler et al., 2017).

Beyond stress and fatigue, the parents of persons with AS also experience increased worry, depression, anxiety, fear, frustration, irritability, loss of control, social isolation and feelings of being unsupported (Wheeler et al., 2017). This understandably impacts parents' relationships with their spouse/partner, other children, extended family and social network 
medRxiv preprint doi: https://doi.org/10.1101/2021.06.03.21258279; this version posted October 11,2021 . The copyright holder for this preprint (which was not certified by peer review) is the author/funder, who has granted medRxiv a license to display the preprint in It is made available under a CC-BY-ND 4.0 International license.

Impact of Angelman syndrome on parental productivity

(Grieco et al., 2019; Wheeler et al., 2017). This may also be further exacerbated by the extent to which the lives of parents and the broader family unit revolve around the needs of the person with AS (Grieco et al., 2019). However, the parental impacts of caring for a person with AS are not limited to the psychosocial, and can also extend into the physical health domain, with many parents and caregivers having experienced back and other chronic pain from lifting and/or assisting their child, as well as other injuries resulting from aggressive behaviours such as hitting, scratching and biting (Grieco et al., 2019; Wheeler et al., 2017). Furthermore, the impacts of caring for a person with AS extend into parents' career choices, with reports of some parents having to change jobs, change careers, decrease their work hours or leave the workforce entirely (Grieco et al., 2019; Wheeler et al., 2017; Willgoss et al., 2020). In addition, those who remain in the workforce may experience greater time off work and reduced productivity while at work, as was estimated in this study (Grieco et al., 2019).

Previous studies estimating the productivity impact of intellectual disability in Australia provide useful context and points of comparison (Arora et al., 2020; Baker et al., 2021; Doran et al., 2012). However, these studies each addressed slightly different research questions, and hence their results are not directly comparable to those described in the present study. Baker et al (2021) estimated the productivity losses arising from the under- and unemployment of individuals with AS from an individual and government perspective. In doing so, Baker et al (2021) found that the mean income tax revenue lost due to the reduced employment of individuals with AS totalled AUD\$19,367 (95\% CI: \$7,785- \$30,949) per annum. By contrast, Arora et al (2020) sought to quantify the costs associated with intellectual disability in childhood in Australia, including costs associated with healthcare, informal care and productivity losses. Arora et al (2020) estimated that the total cost of intellectual disability in Australia was AUD\$72,027 per child and $\$ 12.5$ billion per year, 
medRxiv preprint doi: https://doi.org/10.1101/2021.06.03.21258279; this version posted October 11, 2021. The copyright holder for this preprint (which was not certified by peer review) is the author/funder, who has granted medRxiv a license to display the preprint in It is made available under a CC-BY-ND 4.0 International license.

Impact of Angelman syndrome on parental productivity

including \$142.4 and \$239.3 per month due to paid and unpaid absences from work, respectively. Arora et al (2020) also found that only $47 \%$ of parents reported being employed, but this impact was not included in the productivity losses estimated. Similarly, Doran et al (2012) estimated the cost of intellectual disability in Australia, arriving at a value of AUD $\$ 14.7$ billion per year, with the opportunity cost of lost time accounting for $85 \%$ of this cost. Doran et al (2012) also found that over $70 \%$ of parents sacrifice work opportunities to accommodate their caregiving responsibilities. However, the productivity losses associated with these sacrifices were not estimated (Doran et al., 2012). By contrast, Doble et al (2020) sought to estimate the impact of genomic testing on the total socioeconomic cost of monogenic disorders resulting in intellectual disability, including caregiver productivity costs. Doble et al (2020) found that the costs associated with intellectual disability average USD $\$ 172,000$ per person per year. However, the productivity costs estimated were reported as a combined result for individuals with intellectual disability and their caregivers. As such, the caregiver productivity costs estimated by Doble et al (2020) were unable to be compared to those estimated in the present study. These studies indicate that, in addition to parental productivity costs, intellectual disability results in many other costs to society, families and individuals. These include costs associated with healthcare, aids and modifications, community services, specialist education and day placement services, individual productivity losses (i.e., borne by the disabled person as distinct from those borne by their parents), residential and respite care, formal and informal care, and losses of wellbeing borne by the individual as well as their parents and siblings. As such, the lost parental productivity estimated in the present study is only a fraction of the total socioeconomic cost attributable to AS.

Cost-of-illness studies are used to estimate the socioeconomic impact of a disease or disability on a population (Larg \& Moss, 2011). These studies can be used to raise awareness 
medRxiv preprint doi: https://doi.org/10.1101/2021.06.03.21258279; this version posted October 11, 2021. The copyright holder for this preprint (which was not certified by peer review) is the author/funder, who has granted medRxiv a license to display the preprint in It is made available under a CC-BY-ND 4.0 International license.

of the condition, drive investment in therapeutic research and development, and provide critical inputs to government regulatory and reimbursement decision making (Larg \& Moss, 2011). As such, the present targeted cost-of-illness study could be used to inform government decisions regarding the supports that should be provided to persons with AS and their families (Khan et al., 2019b). In future, it is hoped that these supports will include specific therapeutic treatments for AS, with trials underway at present investigating the efficacy and effectiveness of potentially curative gene therapies for AS. Gene therapies developed and marketed for other conditions have been priced in the order of hundreds of thousands to millions of dollars per dose (Salzman et al., 2018). This means that evidence regarding the total socioeconomic impact, including the parental productivity burden, attributable to AS is needed to inform future health funding decisions.

However, several limitations to the present study warrant mention. First, as discussed, there was uncertainty regarding AS population prevalence and the parental productivity index inputs. Accordingly, results have been presented for the base-case scenario, accompanied by uncertainty ranges. Regardless, the conclusion is unchanged: that the per-parent burden of AS is large. Secondly, the analysis only considered the parental productivity impact of AS over a 10-year period. This short time horizon was adopted to moderate the impact of the uncertainty of key data inputs. Another limitation arose from the assumption that parents who worked remained in the same jobs, and that among those who worked, their hourly contributions to GDP were the same as the average for all working Australians. This approach also assumed that the impact of other mechanisms by which parents contributed to the economy, such as through greater purchasing of healthcare goods and services, were negligible. Previous studies have found that parents of AS children have had to change careers in order to accommodate their caregiving responsibilities, while others reported that their progression in their chosen career track was stunted (Arora et al., 2020; Campbell et al., 
medRxiv preprint doi: https://doi.org/10.1101/2021.06.03.21258279; this version posted October 11, 2021. The copyright holder for this preprint (which was not certified by peer review) is the author/funder, who has granted medRxiv a license to display the preprint in It is made available under a CC-BY-ND 4.0 International license.

Impact of Angelman syndrome on parental productivity

2018). Furthermore, limitations in the granularity of data available to support the estimation of the parental productivity index meant that the parental productivity impact associated with the 'lengthy diagnostic odyssey' commonly experienced by the families of persons with AS was not to be estimated (Wheeler et al., 2017). However, it is anticipated that diagnostic approaches which support reducing the time to an AS diagnosis could have a flow-on benefit of reducing a component of the parental stress associated with having a child with AS (Baker et al., 2021; Doble et al., 2020).

This is the first known study to estimate the total impact of caring for a child with AS on parental productivity, as well as the first study known to estimate the PALYs lost by a parental or caregiver population. If reproduced in future independent studies, this lost parental productivity should be considered when determining the reimbursement strategy for AS therapeutics. Improving parents' ability to participate in the workforce will likely generate significant flow-on benefits to parents' mental health, financial status, and relationships with their spouse/partner; other children; extended family; and social network, as well as to the broader economy.

\section{Acknowledgements}

The authors would like to thank all the study participants and their families for their contributions to the study.

\section{Declarations}

\section{Funding}

This study was supported by the Victorian Government's Operational Infrastructure Support Program; Next Generation Clinical Researchers Program - Career Development Fellowship, funded by the Medical Research Future Fund (MRF1141334 to D.E.G.); and the Foundation for Angelman Syndrome Therapeutics (FAST; Australia to E.K.B. and D.E.G.). 
medRxiv preprint doi: https://doi.org/10.1101/2021.06.03.21258279; this version posted October 11, 2021. The copyright holder for this preprint (which was not certified by peer review) is the author/funder, who has granted medRxiv a license to display the preprint in It is made available under a CC-BY-ND 4.0 International license.

Impact of Angelman syndrome on parental productivity

\section{Conflicts of interest}

E.K.B. and D.E.G. have received funding from the Foundation for Angelman Syndrome Therapeutics (FAST). The authors report that they have no other conflicts or competing interests relevant to the contents of this paper to disclose.

\section{Ethics approval}

The study was approved by the Royal Children's Hospital Human Research Ethics Committee (reference number 33066) and the Monash University Human Research Ethics Committee (reference number 2021-25930-55113). All parents/caregivers provided written informed consent and participants who were deemed cognitively able also provided written informed consent. The authors certify that the study was performed in accordance with the ethical standards as laid down in the 1964 Declaration of Helsinki and its later amendments or comparable ethical standards.

\section{Consent for publication}

Not applicable.

\section{Data, materials and/or code availability}

The datasets generated during and/or analysed during the current study are available from the corresponding author on reasonable request.

\section{Author contributions}

Conceptualization: S.L.H., Data collection: E.K.B., Formal Analysis: S.L.H., Investigation: S.L.H., Methodology: S.L.H., Project Administration: S.L.H., Supervision: D.L., Writing Original Draft: S.L.H., Writing - Review \& Editing: D.L., D.E.G., E.K.B., S.L.H. 
medRxiv preprint doi: https://doi.org/10.1101/2021.06.03.21258279; this version posted October 11, 2021. The copyright holder for this preprint (which was not certified by peer review) is the author/funder, who has granted medRxiv a license to display the preprint in It is made available under a CC-BY-ND 4.0 International license.

AS; Angelman syndrome

CHEERS; Consolidated Health Economic Evaluation Reporting Standards

CSRI; Client Service Receipt Inventory

DS; Dravet syndrome

FTE, full-time equivalent

PALY; productivity-adjusted life year

PDMA; Participant Developmental and Medical Anamnesis

WPAI; Work Productivity and Activity Impairment 
medRxiv preprint doi: https://doi.org/10.1101/2021.06.03.21258279; this version posted October 11,2021 . The copyright holder for this preprint (which was not certified by peer review) is the author/funder, who has granted medRxiv a license to display the preprint in It is made available under a CC-BY-ND 4.0 International license

\section{References}

Ademi, Z., Ackerman, I. N., Zomer, E., \& Liew, D. (2021). Productivity-Adjusted LifeYears: A New Metric for Quantifying Disease Burden. PharmacoEconomics, 39(3), 271-273. https://doi.org/10.1007/s40273-020-00999-z

Al Salloum, A., El Mouzan, M. I., Al Herbish, A., Al Omer, A., \& Qurashi, M. (2015). Prevalence of selected congenital anomalies in Saudi children: a community-based study. Annals of Saudi Medicine, 35(2), 107-110. https://doi.org/10.5144/02564947.2015.107

Arora, S., Goodall, S., Viney, R., \& Einfeld, S. (2020). Societal cost of childhood intellectual disability in Australia. Journal of Intellectual Disability Research, 64(7), 524-537. https://doi.org/10.1111/jir.12732

Baker, E. K., Arora, S., Amor, D. J., Date, P., Cross, M., O’Brien, J., Simons, C., Rogers, C., Goodall, S., Slee, J., Cahir, C., \& Godler, D. E. (2021). The Cost of Raising Individuals with Fragile X or Chromosome 15 Imprinting Disorders in Australia. Journal of Autism and Developmental Disorders, 0123456789. https://doi.org/10.1007/s10803-021-051934

Baker, E. K., Godler, D. E., Bui, M., Hickerton, C., Rogers, C., Field, M., Amor, D. J., \& Bretherton, L. (2018). Exploring autism symptoms in an Australian cohort of patients with Prader-Willi and Angelman syndromes. Journal of Neurodevelopmental Disorders, 10(1), 24. https://doi.org/10.1186/s11689-018-9242-0

Births. (2019). Australian Bureau of Statistics.

https://www.abs.gov.au/statistics/people/population/births-australia/latest-release\#datadownload

Buntinx, I. M., Hennekam, R. C. M., Brouwer, O. F., Stroink, H., Beuten, J., Mangelschots, K., \& Fryns, J. P. (1995). Clinical profile of Angelman syndrome at different ages. American Journal of Medical Genetics, 56(2), 176-183. 
medRxiv preprint doi: https://doi.org/10.1101/2021.06.03.21258279; this version posted October 11, 2021. The copyright holder for this preprint (which was not certified by peer review) is the author/funder, who has granted medRxiv a license to display the preprint in It is made available under a CC-BY-ND 4.0 International license.

Impact of Angelman syndrome on parental productivity

https://doi.org/10.1002/ajmg.1320560213

Campbell, J. D., Whittington, M. D., Kim, C. H., VanderVeen, G. R., Knupp, K. G., \&

Gammaitoni, A. (2018). Assessing the impact of caring for a child with Dravet

syndrome: Results of a caregiver survey. Epilepsy \& Behavior, 80, 152-156.

https://doi.org/10.1016/j.yebeh.2018.01.003

Characteristics of Employment. (2020). Australian Bureau of Statistics.

https://www.abs.gov.au/statistics/labour/earnings-and-work-hours/characteristics-

employment-australia/latest-release

Coppus, A. M. W. (2013). People with intellectual disability: What do we know about adulthood and life expectancy? Developmental Disabilities Research Reviews, 18(1), 616. https://doi.org/10.1002/ddrr.1123

Dagli, A., Buiting, K., \& Williams, C. A. (2011). Molecular and Clinical Aspects of Angelman Syndrome. Molecular Syndromology, 2(3-5), 100-112.

https://doi.org/10.1159/000328837

Deaths. (2019). Australian Bureau of Statistics.

https://www.abs.gov.au/statistics/people/population/deaths-australia/latest-release

Disability, Ageing and Carers. (2018). Australian Bureau of Statistics.

https://www.abs.gov.au/statistics/health/disability/disability-ageing-and-carers-australiasummary-findings/latest-release\#data-download

Doble, B., Schofield, D., Evans, C.-A., Groza, T., Mattick, J. S., Field, M., \& Roscioli, T. (2020). Impacts of genomics on the health and social costs of intellectual disability. Journal of Medical Genetics, 57(7), 479-486. https://doi.org/10.1136/jmedgenet-2019106445

Domínguez-Berjón, M. F., Zoni, A. C., Esteban-Vasallo, M. D., Sendra-Gutiérrez, J. M., \& Astray-Mochales, J. (2018). Main causes of hospitalization in people with Angelman 
medRxiv preprint doi: https://doi.org/10.1101/2021.06.03.21258279; this version posted October 11,2021 . The copyright holder for this preprint (which was not certified by peer review) is the author/funder, who has granted medRxiv a license to display the preprint in It is made available under a CC-BY-ND 4.0 International license.

Impact of Angelman syndrome on parental productivity

syndrome. Journal of Applied Research in Intellectual Disabilities, 31(3), 466-469. https://doi.org/10.1111/jar.12411

Doran, C. M., Einfeld, S. L., Madden, R. H., Otim, M., Horstead, S. K., Ellis, L. A., \& Emerson, E. (2012). How much does intellectual disability really cost? First estimates for Australia. Journal of Intellectual \& Developmental Disability, 37(1), 42-49. https://doi.org/10.3109/13668250.2011.648609

Giovannetti, E. R., Wolff, J. L., Frick, K. D., \& Boult, C. (2009). Construct Validity of the Work Productivity and Activity Impairment Questionnaire across Informal Caregivers of Chronically Ill Older Patients. Value in Health, 12(6), 1011-1017. https://doi.org/10.1111/j.1524-4733.2009.00542.x

Goldman, S. E., Bichell, T. J., Surdyka, K., \& Malow, B. A. (2012). Sleep in children and adolescents with Angelman syndrome: association with parent sleep and stress. Journal of Intellectual Disability Research, 56(6), 600-608. https://doi.org/10.1111/j.13652788.2011.01499.x

Grieco, J. C., Romero, B., Flood, E., Cabo, R., \& Visootsak, J. (2019). A Conceptual Model of Angelman Syndrome and Review of Relevant Clinical Outcomes Assessments (COAs). The Patient - Patient-Centered Outcomes Research, 12(1), 97-112. https://doi.org/10.1007/s40271-018-0323-7

Griffith, G. M., Hastings, R. P., Oliver, C., Howlin, P., Moss, J., Petty, J., \& Tunnicliffe, P. (2011). Psychological well-being in parents of children with Angelman, Cornelia de Lange and Cri du Chat syndromes. Journal of Intellectual Disability Research, 55(4), 397-410. https://doi.org/10.1111/j.1365-2788.2011.01386.x

Husereau, D., Drummond, M., Petrou, S., Carswell, C., Moher, D., Greenberg, D., Augustovski, F., Briggs, A. H., Mauskopf, J., \& Loder, E. (2013). Consolidated Health Economic Evaluation Reporting Standards (CHEERS) statement. The European Journal 
medRxiv preprint doi: https://doi.org/10.1101/2021.06.03.21258279; this version posted October 11,2021 . The copyright holder for this preprint (which was not certified by peer review) is the author/funder, who has granted medRxiv a license to display the preprint in It is made available under a CC-BY-ND 4.0 International license

Impact of Angelman syndrome on parental productivity

of Health Economics, 14(3), 367-372. https://doi.org/10.1007/s10198-013-0471-6

Jørgensen, I. F., Russo, F., Jensen, A. B., Westergaard, D., Lademann, M., Hu, J. X., Brunak, S., \& Belling, K. (2019). Comorbidity landscape of the Danish patient population affected by chromosome abnormalities. Genetics in Medicine, 21(11), 2485-2495. https://doi.org/10.1038/s41436-019-0519-9

Khan, N., Cabo, R., Tan, W.-H., Tayag, R., \& Bird, L. M. (2019a). An observational study of pediatric healthcare burden in Angelman syndrome: results from a real-world study. Orphanet Journal of Rare Diseases, 14(1), 239. https://doi.org/10.1186/s13023-019$1210-6$

Khan, N., Cabo, R., Tan, W., Tayag, R., \& Bird, L. M. (2019b). Healthcare burden among individuals with Angelman syndrome: Findings from the Angelman Syndrome Natural History Study. Molecular Genetics \& Genomic Medicine, 7(7), 1-8.

https://doi.org/10.1002/mgg3.734

Larg, A., \& Moss, J. R. (2011). Cost-of-Illness Studies. PharmacoEconomics, 29(8), 653671. https://doi.org/10.2165/11588380-000000000-00000

Luk, H. M., \& Lo, I. F. M. (2016). Angelman syndrome in Hong Kong Chinese: A 20 years' experience. European Journal of Medical Genetics, 59(6-7), 315-319.

https://doi.org/10.1016/j.ejmg.2016.05.003

Mertz, L. G. B., Christensen, R., Vogel, I., Hertz, J. M., Nielsen, K. B., Grønskov, K., \& Østergaard, J. R. (2013). Angelman syndrome in Denmark. Birth incidence, genetic findings, and age at diagnosis. American Journal of Medical Genetics Part A, 161(9), 2197-2203. https://doi.org/10.1002/ajmg.a.36058

Miodrag, N., \& Peters, S. (2015). Parent stress across molecular subtypes of children with Angelman syndrome. Journal of Intellectual Disability Research, 59(9), 816-826. https://doi.org/10.1111/jir.12195 
medRxiv preprint doi: https://doi.org/10.1101/2021.06.03.21258279; this version posted October 11,2021 . The copyright holder for this preprint (which was not certified by peer review) is the author/funder, who has granted medRxiv a license to display the preprint in It is made available under a CC-BY-ND 4.0 International license.

National, state and territory population. (2020). Australian Bureau of Statistics.

https://www.abs.gov.au/statistics/people/population/national-state-and-territorypopulation/jun-2020\#data-download

National income, expenditure and product. (2020). Australian Bureau of Statistics.

https://www.abs.gov.au/statistics/economy/national-accounts/australian-nationalaccounts-national-income-expenditure-and-product/latest-release\#data-download

Õiglane-Shlik, E., Talvik, T., Žordania, R., Põder, H., Kahre, T., Raukas, E., Ilus, T., Tasa, G., Bartsch, O., Väisänen, M.-L., \& Õunap, K. (2006). Prevalence of Angelman syndrome and Prader-Willi syndrome in Estonian children: Sister syndromes not equally represented. American Journal of Medical Genetics Part A, 140A(18), 19361943. https://doi.org/10.1002/ajmg.a.31423

Petersen, M. B., Brøndum-Nielsen, K., Hansen, L. K., \& Wulff, K. (1995). Clinical, cytogenetic, and molecular diagnosis of Angelman syndrome: Estimated prevalence rate in a Danish county. American Journal of Medical Genetics, 60(3), 261-262. https://doi.org/10.1002/ajmg.1320600317

Salzman, R., Cook, F., Hunt, T., Malech, H. L., Reilly, P., Foss-Campbell, B., \& Barrett, D. (2018). Addressing the Value of Gene Therapy and Enhancing Patient Access to Transformative Treatments. Molecular Therapy, 26(12), 2717-2726. https://doi.org/10.1016/j.ymthe.2018.10.017

Thomson, A., Glasson, E., \& Bittles, A. (2006). A long-term population-based clinical and morbidity profile of Angelman syndrome in Western Australia: 1953-2003. Disability and Rehabilitation, 28(5), 299-305. https://doi.org/10.1080/09638280500190631

Thomson, A., Glasson, E., Roberts, P., \& Bittles, A. (2017). "Over time it just becomes easier...": parents of people with Angelman syndrome and Prader-Willi syndrome speak about their carer role. Disability and Rehabilitation, 39(8), 763-770. 
medRxiv preprint doi: https://doi.org/10.1101/2021.06.03.21258279; this version posted October 11,2021 . The copyright holder for this preprint (which was not certified by peer review) is the author/funder, who has granted medRxiv a license to display the preprint in It is made available under a CC-BY-ND 4.0 International license.

Impact of Angelman syndrome on parental productivity

https://doi.org/10.3109/09638288.2016.1161838

Tones, M., Cross, M., Simons, C., Napier, K. R., Hunter, A., Bellgard, M. I., \& Heussler, H. (2018). Research protocol: The initiation, design and establishment of the Global Angelman Syndrome Registry. Journal of Intellectual Disability Research, 62(5), 431443. https://doi.org/10.1111/jir.12482

van den Borne, H. W., van Hooren, R. H., van Gestel, M., Rienmeijer, P., Fryns, J. P., \& Curfs, L. M. G. (1999). Psychosocial problems, coping strategies, and the need for information of parents of children with Prader-Willi syndrome and Angelman syndrome. Patient Education and Counseling, 38(3), 205-216.

https://doi.org/10.1016/S0738-3991(99)00004-X

Wheeler, A. C., Sacco, P., \& Cabo, R. (2017). Unmet clinical needs and burden in Angelman syndrome: a review of the literature. Orphanet Journal of Rare Diseases, 12(1), 164. https://doi.org/10.1186/s13023-017-0716-z

Willemsen, M. H., Rensen, J. H. M., van Schrojenstein-Lantman de Valk, H. M. J., Hamel, B. C. J., \& Kleefstra, T. (2012). Adult Phenotypes in Angelman- and Rett-Like Syndromes. Molecular Syndromology. https://doi.org/10.1159/000335661

Willgoss, T., Cassater, D., Connor, S., Krishnan, M. L., Miller, M. T., Dias-Barbosa, C., Phillips, D., McCormack, J., Bird, L. M., Burdine, R. D., Claridge, S., \& Bichell, T. J. (2020). Measuring What Matters to Individuals with Angelman Syndrome and Their Families: Development of a Patient-Centered Disease Concept Model. Child Psychiatry \& Human Development. https://doi.org/10.1007/s10578-020-01051-z

Wulffaert, J., Scholte, E. M., \& Van Berckelaer-Onnes, I. A. (2010). Maternal parenting stress in families with a child with Angelman syndrome or Prader-Willi syndrome. Journal of Intellectual \& Developmental Disability, 35(3), 165-174.

https://doi.org/10.3109/13668250.2010.499101 
Tables

Table 1 The productivity burden borne by the parents of persons with AS in Australia over a 10-year period

\begin{tabular}{lrrr} 
& Fathers & Mothers & Total \\
\hline PALYs lost & & & \\
Total (PALYs) & base-case: 183.40 & base-case: 311.66 & base-case: 495.06 \\
& (lower: 73.36 , upper: $1,321.58)$ & (lower: 124.66, upper: 733.60$)$ & (lower: 198.02, upper: $1,246.62)$ \\
Per parent (PALYs) & 1.18 & 1.79 & 1.50 \\
Proportion per parent (\%) & 25.19 & 53.05 & 38.42 \\
Cost to society & & & base-case: 45.30 \\
Total (AUD\$, million) & base-case: 19.98 & base-case: 25.32 & (lower: 18.12, upper: 181.20$)$ \\
Per parent (AUD\$) & (lower: 7.99, upper: 79.93$)$ & (lower: 10.13, upper: 101.27$)$ & $137,105.94$ \\
\hline
\end{tabular}


Figures

Figure 1 Distribution of the number of people with AS in Australia by age and sex (base-case scenario)

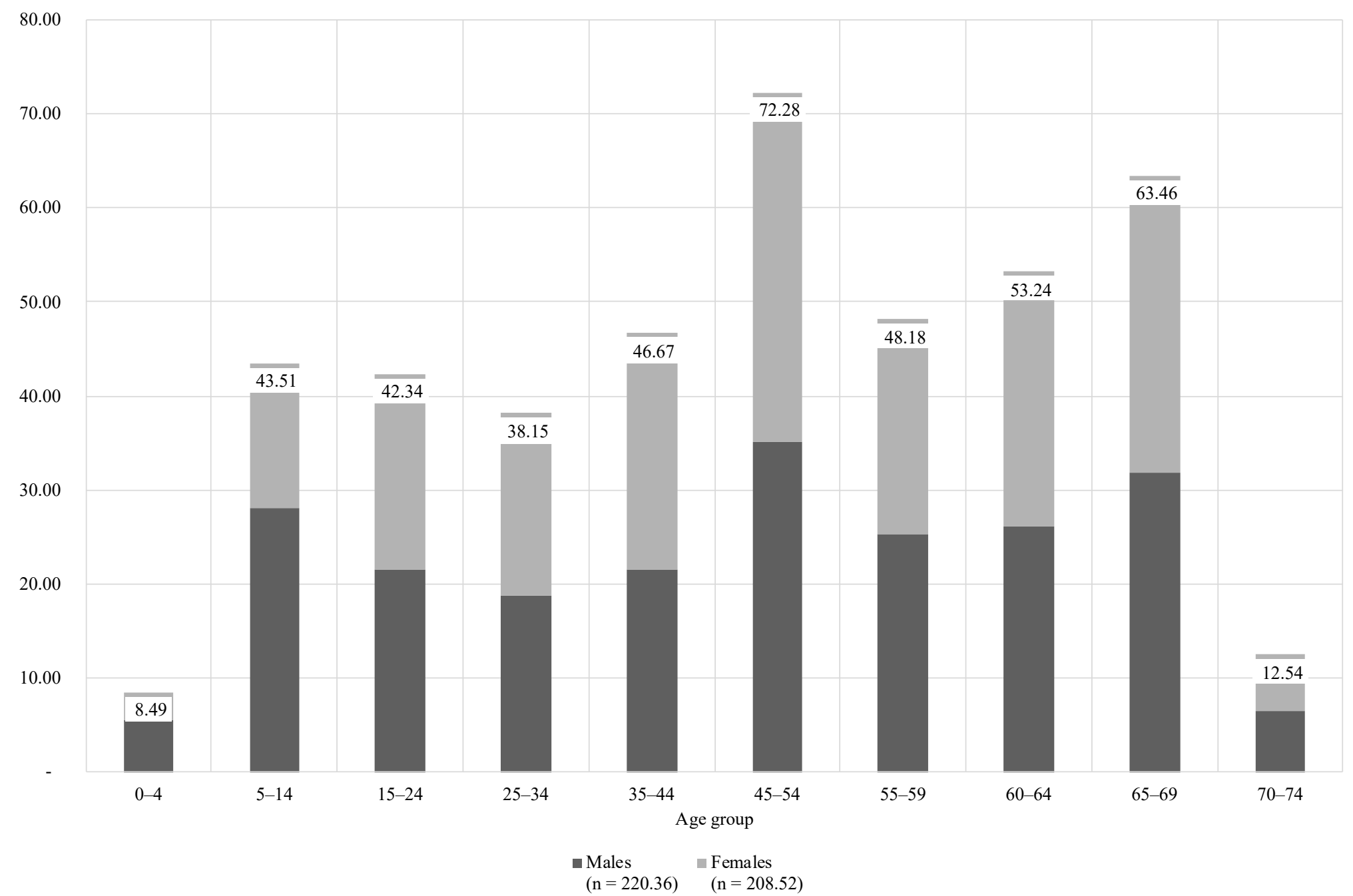


Figure 2 Distribution of the number of parents of people with AS in Australia by age and sex (base-case scenario)

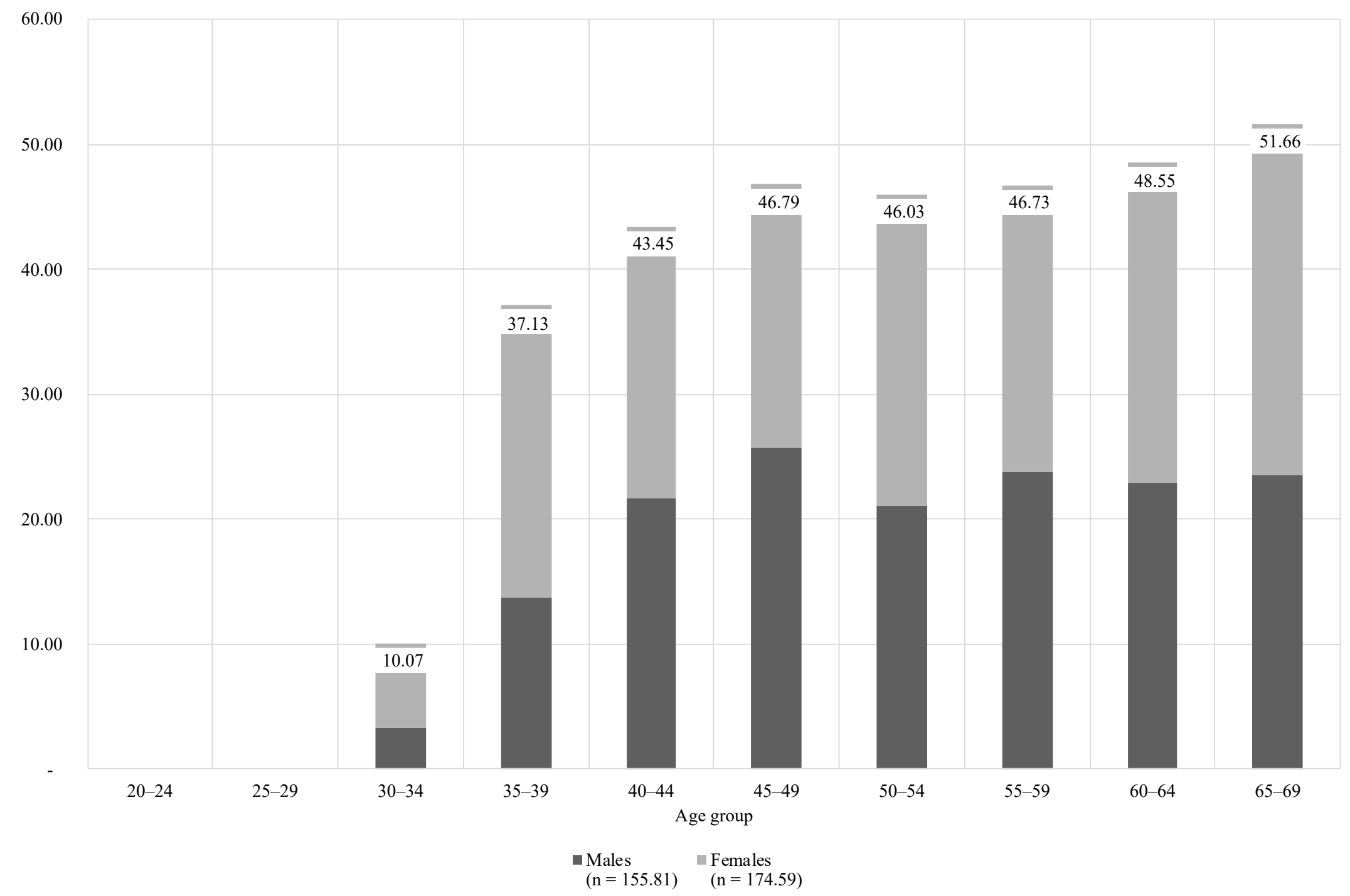


Figure 3 The proportion of PALYs lost by the parents of persons with AS in Australia over a 10-year period by age and sex

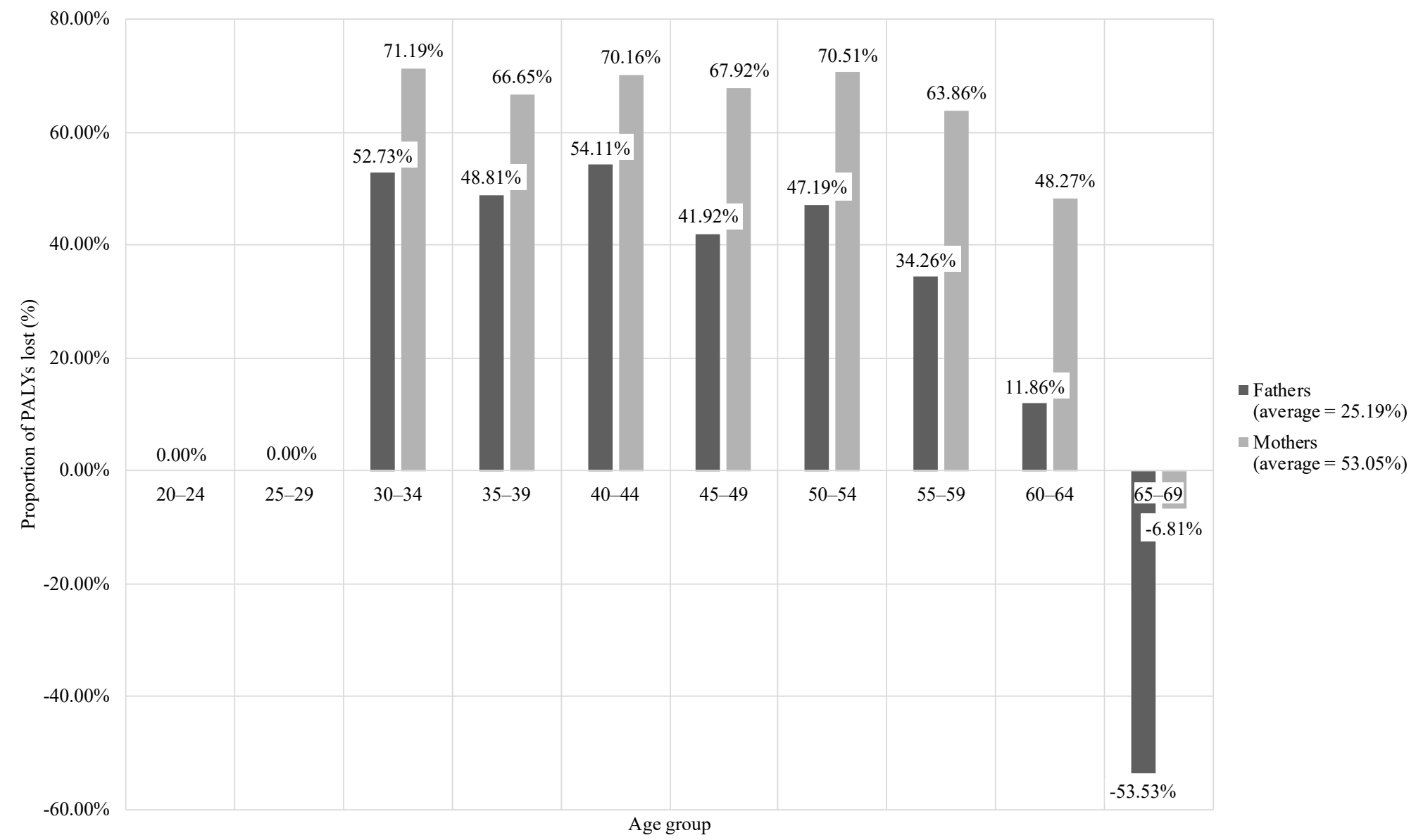

Note: A negative productivity loss was estimated for the 65-to-69-year age group due to the lack of age specific parental productivity indices, resulting in the parental population accruing greater PALYs in this age group than the control population. 
Figure 4 Sensitivity analyses (a) effect of $+/-20 \%$ average parental workforce participation on PALYs lost (b) effect of $+/-20 \%$ attributable absenteeism on PALYs lost (c) effect of $+/-20 \%$ attributable presenteeism on PALYs lost

(a)

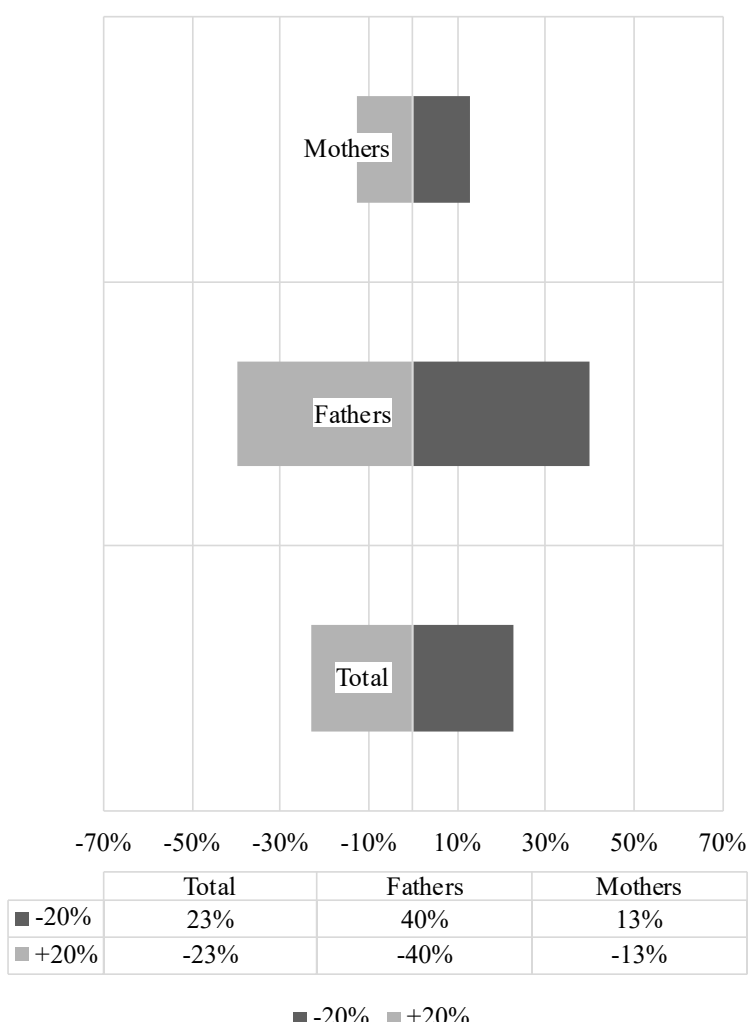

(b)

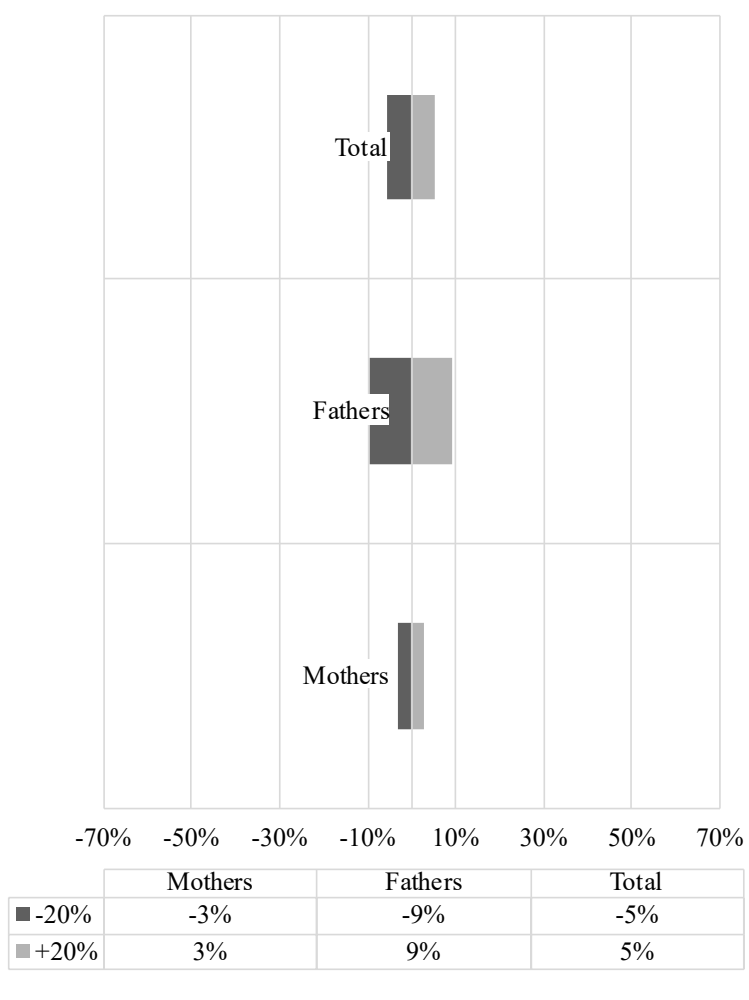

$\square-20 \%-+20 \%$ (c)

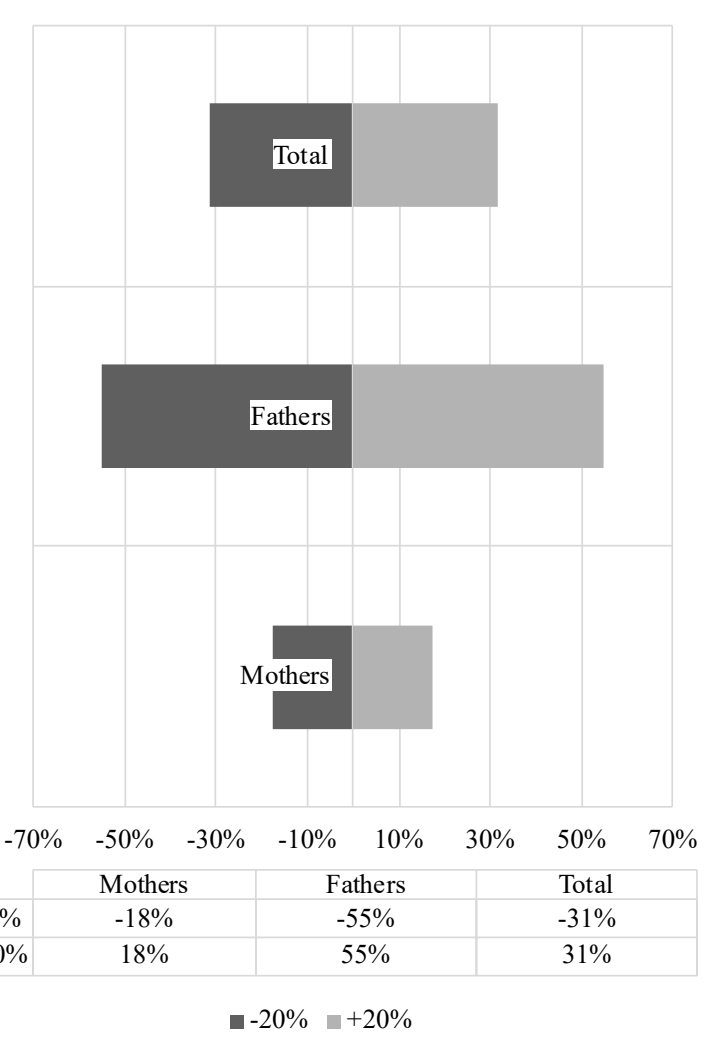




\section{Supplementary information}

Figure S1 Structure of the cost-of-illness model developed to estimate the productivity burden borne by the parents of persons over a 10-year period in Australia

Table S1 Key cost-of-illness model inputs

Table S2 Assumptions underlying the cost-of-illness modelling approach 